\title{
DYNAMIC STABILITY ANALYSIS OF THE LAMINATED COMPOSITE CURVED FRAME STRUCTURES
}

\author{
Ŏguzhan DAS \\ Hasan ÖZTÜRK \\ Can GÖNENL $\dot{I}^{\prime}$
}

Received: 13.04.2021; revised: 08.07.2021; accepted: 08.07.2021

\begin{abstract}
In this study, the dynamic stability analysis of the laminated composite single-bay and two-bay curved frame structures has been investigated. For this purpose, a computer code is written in MATLAB to evaluate the natural frequency values, critical buckling load, and first unstable regions of the laminated composite curved frames. The effects of radii of curvature and stacking order on the static and dynamic stability of both single and two bay arch frame structures are investigated. Besides, the effects of the stacking order are investigated by considering five different stacking sequences. The results of the present study are compared with the results obtained numerically via ANSYS for validation. It is concluded that the radius of curvature has a small effect on the first five natural frequency values, buckling loads, first unstable regions of the structure, whereas the fiber orientation considerably has a considerable impact on such static and dynamic properties.
\end{abstract}

Keywords: Dynamic Stability, Finite Element Method, Curved Composite Frames, Vibration, Buckling

\section{Katmanlı Eğri Kompozit Çerçeve Yapıların Dinamik Kararlılık Analizi}

Öz: Bu çalışmada tek ve iki bölütlü tabakalı eğri kompozit çerçeve yapıların dinamik kararlılık analizleri incelenmiş̧ir. Bunun için, MATLAB ortamında yazılan bir bilgisayar kodu vasıtasıyla tabakalı kompozit eğri çerçeve yapıların doğal frekansları, kritik burkulma yükü ve birinci kararsızlık bölgeleri ele alınmıştır. Bu kapsamda hem tek bölütlü hem de çift bölütlü yapının eğrilik yarıçapının statik ve dinamik kararlılığı üzerine olan etkileri araştırılmıştır. Ayrıca, beş farklı fiber açısı düzeni dikkate alınarak farklı fiber açılarının da bu özellikler üzerindeki etkisi incelenmiștir. Kullanılan sonlu eleman modelinin doğruluğu aynı yapının ANSYS ortamında modellenmesi ve analizinden elde edilen sonuçlarla karşılaştırılarak sağlanmıştır. Çalışmanın sonucunda eğrilik yarıçapının yapının ilk beş doğal frekansı, kritik burkulma yükü ve birinci kararsızlık bölgesi üzerinde küçük bir etkisinin olduğu gözlemlenirken elyaf oryantasyonunun bu özellikler üzerinde kayda değer bir etki oluşturduğu tespit edilmiştir.

Anahtar Kelimeler: Dinamik Kararlılık, Sonlu Elemanlar Yöntemi, Eğri Kompozit Çerçeveler, Titreşim, Burkulma

\footnotetext{
* Oğuzhan DAŞ, Dokuz Eylül Üniversitesi, Bergama Meslek Yüksekokulu - Motorlu Araçlar ve Ulaştırma Teknolojileri Bölümü, 35700, Bergama/İzmir

**Hasan ÖZTÜRK, Dokuz Eylül Üniversitesi, Mühendislik Fakültesi - Makine Mühendisliği Bölümü, 35390, Buca/İzmir

$\dagger$ Can GÖNENLİ, Ege Üniversitesi, Ege Meslek Yüksekokulu - Makine Resim ve Konstrüksiyonu Programı, 35100, Bornova/İzmir

İletişim Yazarı: Oğuzhan Daş (oguzhan.das@deu.edu.tr)
} 
Daş O., Öztürk H., Gönenli C.: Dynamic Stabil. Analys. of the Laminated Compos. Curved Frame Struc.

\section{INTRODUCTION}

Laminated composite structures are widely used in aerospace, automotive, civil engineering, marine applications because of their various advantages such as design flexibility, perfect corrosion and fatigue resistance, and high strength to weight ratio. On the other hand, these structures have to design and analyzed meticulously since they may not operate under desired conditions. Dynamic and static instabilities are the phenomenon that may occur under periodic and static loading conditions, which may lead the structure to fail. Considering a structure that operates under a static or dynamic load, determining such a structure's dynamic and static characteristics. One of the well-known studies about the dynamic stability problem is Bolotin's approach (Bolotin, 1964), where the effect of an elastic foundation on the critical buckling loads and natural frequency values of a Bernoulli-Euler beam hinged from both ends is investigated. Marur and Kant (1996) presented three higher-order refined displacement models to perform free vibration analysis of sandwich and composite beams using finite element modeling. Hodges, et al. (1991) presented various methods to determine the natural frequencies and mode shapes of composite beams. Ozturk (2015) investigated free vibration analysis of pre-stressed curved symmetric and asymmetric composite beams under fixed from two ends boundary conditions. Vo et al. (2017) presented free vibration of axially loaded composite beams using a four-unknown shear and normal deformation theory by employing a two-node $\mathrm{C} 1$ beam element. Vo-Duy et al. (2019) performed a free vibration analysis of laminated functionally graded carbon nanotubereinforced composite beams using the finite element method. Eken (2019) investigated the free vibration analysis of composite aircraft wings by considering them as thin-walled beams with NACA airfoil sections. Alambeigi et al. (2020) conducted free and forced vibration analysis of sandwich beam having shape memory alloy embedded composite face layers and functionally graded porous core. They considered Hamilton's principle and first-order shear deformation theory to derive the governing equations of motions of the beam which is rested on Vlasov's foundation. Qin et al. (2020) examined the vibration characteristics of the composite curved beams. For this purpose, they considered elliptical, parabolic, hyperbolic, and circular curved beams. Besides, they also measured the effects of the boundary conditions and fiber orientations on the natural frequencies of curved composite beam structures. Lee and Kim (2002) investigated the lateral buckling analysis of laminated thin-walled channel-section composite beams using classical lamination theory. Goyal and Kapania (2007) presented a 21 degree of freedom element to perform buckling and vibration analysis of laminated composite beams. For this purpose, they employed the first-order shear deformation theory. Zabihollah and Ganesan (2010) investigated the buckling behavior of tapered composite beams using higher-order finite element formulation. He and Yang (2014) studied buckling analysis of two-layer composite Timoshenko beams using the finite element method based on the higher-order beam theory. Wang, et al. (2015) investigated the buckling analysis of laminated composite beams under different boundary conditions using the isogeometric finite element method based on non-uniform rational b-splines. Kahya (2016) studied finite element buckling analysis of laminated composite and sandwich beams using multilayered beam elements whose degrees of freedom vary to the number of layers of the composite and sandwich beams. Huang and Qiao (2020) performed buckling analysis of thinwalled curved composite beams with I-section. They presented a closed-form solution to determine the buckling load of the structure under bending moment and compression.Tsai and Chen (2002) conducted a dynamic stability analysis of the shape memory alloy wire reinforced composite beam using the finite element method and harmonic balance method. Yeh and Kuo (2004) investigated the dynamic stability of composite plates under parametric excitation considering the effects of the length, width, thickness, and fiber orientation of the beam on instability. Ozturk et al. (2006) employed the Finite Element Method to investigate the in-plane stability analysis of curved beams with non-uniform cross-section. Machado and Cortínez (2009) studied the dynamic stability of periodically excited thin-walled composite beams using a seven degree of freedom shear deformable beam theory. Saravia et al. (2011) investigated the dynamic 
stability of thin-walled rotating composite beams by employing the finite element method based on Bolotin's approach. Ke et al. (2013) performed the dynamic stability analysis of functionally graded nanocomposite beams by using the Timoshenko Beam Theory. They used Bolotin's method to determine the unstable regions of the nanocomposite beams. Goren Kiral et al. (2015) performed a stability analysis for delaminated woven and laminated composite cantilever beams with different stacking sequences Smolijanović et al. (2020) utilized two numerical models, which are Model L and Model N, in the dynamic stability analysis of beam structures. They employed these numerical models with Y-FDEM, which is an open-source finite discrete element package. Glabisz et al. (2020) presented a universal algorithm to analyze the stability of EulerBernoulli nanobeams subjected to arbitrary loads. They conducted the analysis by considering the exact solutions of each prismatic nanobeam segment.

In this study, the dynamic stability of the laminated composite arch frame structures has been examined. The Finite Element Method is employed with Classical Plate Theory (CPT). The effects of the radius of curvature and stacking order of the single-bay and two-bay structures on the first five natural frequencies, critical buckling load, and unstable first regions are investigated. Although there are many studies reported in the literature covering the dynamic stability analysis of various composite structures mentioned above, the dynamic stability of curved frame structures has not been investigated. In this study, the vibration, buckling, and first unstable regions of curved frames are investigated to fill this gap. Besides, the effects of the stacking order and radius of curvature on such dynamic characteristics are examined.

\section{MATHEMATICAL MODEL}

\subsection{Theory of the Dynamic Stability}

Figures 1 and 2 show the laminated composite arch (curved) frame subjected to periodically compressive distributed load, $W(t)$. Such a loading case can be defined in terms of static and timedependent loads as

$$
W(t)=P+P_{t} \cos \lambda t=\alpha P_{c r}+\beta P_{c r} \cos \lambda t, \alpha=\frac{P}{P_{c r}}, \beta=\frac{P_{t}}{P_{c r}}
$$

where $\lambda$ is the excitation frequency, $P$ and $P_{t}$ are the amplitudes of the static and time-variant periodic compressive load, respectively. Those two force components of the compressive load can be written by dividing them to the static buckling load Pcr as given in Equation (1) (Goren Kiral et al., 2015) where $\alpha$ and $\beta$ denote the static and dynamic load factors, respectively. 
Daş O., Öztürk H., Gönenli C.: Dynamic Stabil. Analys. of the Laminated Compos. Curved Frame Struc.

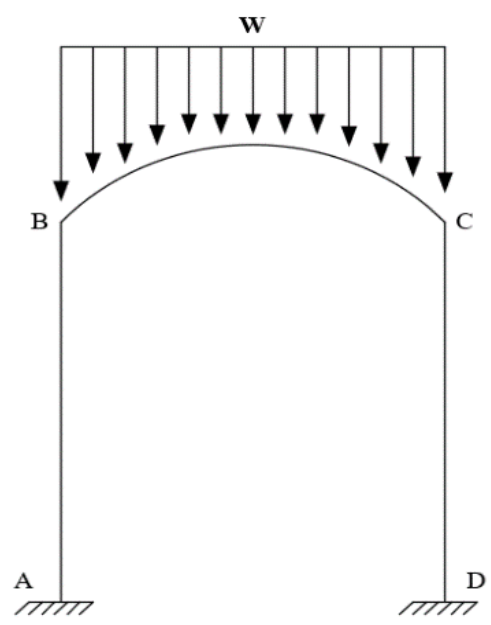

Figure 1:

Distributed loading condition of single-bay laminated composite arch (curved) frame structure

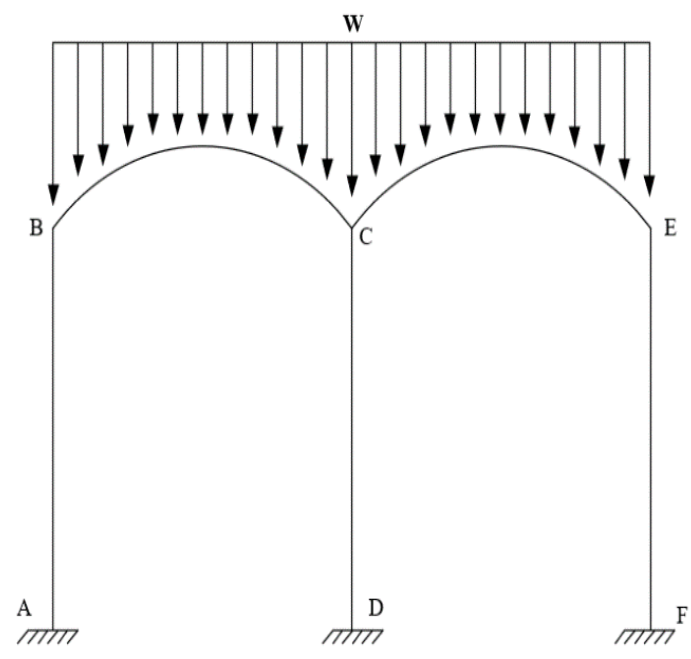

Figure 2:

Distributed loading condition of two-bay laminated composite arch (curved) frame structure

The dynamic response of the laminated composite arch (curved) frame can be formulated through Lagrange's equation of motion. Hence, the governing equation of motion is

$$
\boldsymbol{M} \ddot{\boldsymbol{q}}+\boldsymbol{K} \boldsymbol{q}-W(t) \boldsymbol{K}_{\boldsymbol{g}} \boldsymbol{q}=0
$$

where $\mathbf{q}$ is the generalized displacement coordinates. $\mathbf{M}, \mathbf{K}$, and $\mathbf{K}_{\mathbf{g}}$ are the mass matrix, elastic stiffness, matrix, and geometric stiffness matrix of the structure, respectively. Substituting Equation (1) into Equation (2) gives 


$$
\boldsymbol{M} \ddot{\boldsymbol{q}}+\left(\boldsymbol{K}-\alpha P_{c r} \boldsymbol{K}_{\boldsymbol{g s t}}-\left(\beta P_{c r} \cos \lambda t\right) \boldsymbol{K}_{\boldsymbol{g t}}\right) \boldsymbol{q}=0
$$

$\mathbf{K}_{\mathbf{g s t}}$ and $\mathbf{K}_{\mathbf{g t}}$ represent the effect of the static and time-variant force components, $P$ and $P_{t}$, respectively. Equation (3) reflects a second-order differential equation system, including periodic components of the Mathieu-Hill expression. $\mathbf{K}_{\mathbf{g s t}}$ and $\mathbf{K}_{\mathrm{gt}}$ become identical when the static and dynamic components of the subjected compressive load are applied in the same way. Therefore, Equation (3) can be written as,

$$
\boldsymbol{M} \ddot{\boldsymbol{q}}+\left(\boldsymbol{K}-P_{\mathrm{cr}}(\alpha+\beta \cos \lambda \mathrm{t}) \boldsymbol{K}_{\boldsymbol{g}}\right) \boldsymbol{q}=0
$$

Equation (4) can be solved by using the finite element method, as explained below.

\subsection{Finite Element Method}

To solve the eigenvalue problem given in Equation (4), the Finite Element Method is employed with Classical Plate Theory (CPT). the moment equation for unit length is (Petyt, 2010),

$$
\begin{gathered}
\left\{\begin{array}{l}
M_{x x} \\
M_{y y} \\
M_{x y}
\end{array}\right\}=\left[\begin{array}{lll}
D_{11} & D_{12} & D_{16} \\
D_{12} & D_{22} & D_{26} \\
D_{16} & D_{26} & D_{66}
\end{array}\right]\left\{\begin{array}{c}
\frac{\partial^{2} w}{\partial x^{2}} \\
\frac{\partial^{2} w}{\partial y^{2}} \\
2 \frac{\partial^{2} w}{\partial x \partial y}
\end{array}\right\} \\
\left\{\begin{array}{c}
\frac{\partial^{2} w}{\partial x^{2}} \\
\frac{\partial^{2} w}{\partial y^{2}} \\
2 \frac{\partial^{2} w}{\partial x \partial y}
\end{array}\right\}=\left[\begin{array}{lll}
D_{11}^{*} & D_{12}^{*} & D_{16}^{*} \\
D_{12}^{*} & D_{22}^{*} & D_{26}^{*} \\
D_{16}^{*} & D_{26}^{*} & D_{66}^{*}
\end{array}\right]\left\{\begin{array}{l}
M_{x x} \\
M_{y y} \\
M_{x y}
\end{array}\right\}
\end{gathered}
$$

where $M_{x x}, M_{y y}$, and $M_{x y}$ are the moments, $D_{i j}^{*}$ denotes the inverse of the $D_{i j}$, which is the components of the bending stiffness matrix. $D_{i j}$ is given by

$$
D_{i j}=\frac{1}{3} \sum_{k=1}^{N L} Q_{i j}^{k}\left(z_{k+1}^{3}-z_{k}^{3}\right), \quad i, j=1,2,6
$$

where $N L$ is the number of laminates, $Q_{i j}$ is the stiffnesses given in Appendix A, and $z$ is the variable of the coordinate of the $k^{\text {th }}$ laminate, shown in Figure 3. It is assumed that $M_{y y}=M_{x y}=0$ for laminated beam theory (Ozturk, 2015). Hence,

$$
\frac{\partial^{2} w}{\partial x^{2}}=D_{11}^{*} M_{x x}
$$


Daş O., Öztürk H., Gönenli C.: Dynamic Stabil. Analys. of the Laminated Compos. Curved Frame Struc.

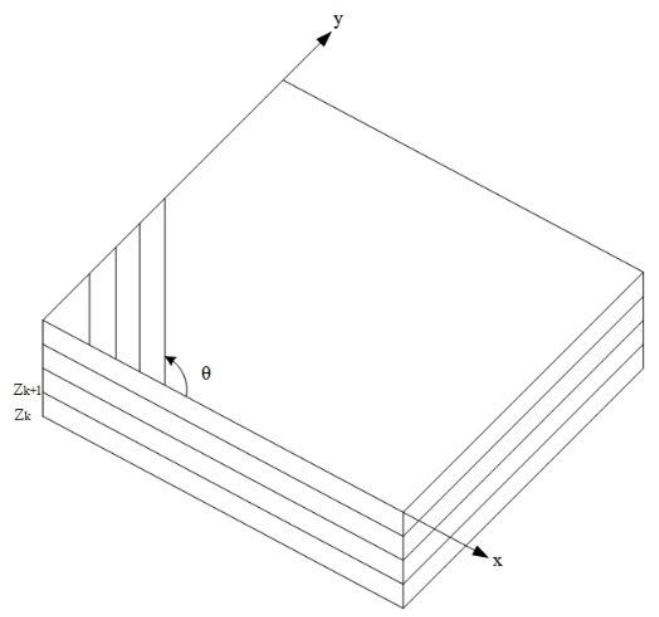

Figure 3:

Laminated composite material

Equation (7) can be written in a form that is well-known in Euler-Bernoulli beam theory as

$$
M=b M_{x x}, \quad M_{x x}=E_{x x} I \frac{\partial^{2} w}{\partial x^{2}}, \quad E_{x x}=E_{e f f}=\frac{12}{h^{3} D_{11}^{*}}
$$

where $E_{x x}$ or $E_{\text {eff }}$ is the effective flexural modulus, $b$, and $h$ are the width and thickness of the finite element. Figure 4 shows the frame element having 3 degrees of freedom (DOF) to perform finite element analysis where $u, w$, and $\theta$ denote the longitudinal displacement, bending displacement, and slope of the laminated composite arch (curved) frame structure, respectively.

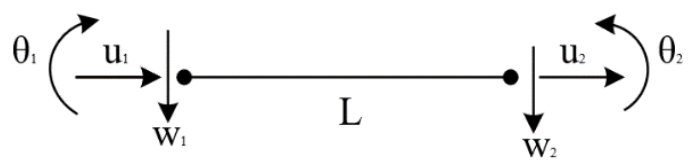

Figure 4:

Frame element

Equation (9) denotes the displacement equations of the frame element (Petyt, 2010).

$$
\begin{gathered}
u=a_{1}+a_{2} x \\
w=a_{3}+a_{4} x+a_{5} x^{2}+a_{6} x^{3} \\
\theta=\frac{d w}{d x}
\end{gathered}
$$

The generalized displacement vector of the frame element is given in Equation (10).

$$
\{q\}=\left[\begin{array}{llllll}
u_{1} & w_{1} & \theta_{1} & u_{2} & w_{2} & \theta_{2}
\end{array}\right]
$$


Equations (11) and (12) give the strain and kinetic energy equations of the frame element, respectively (Petyt, 2010).

$$
\begin{gathered}
U_{e}=\frac{1}{2} E_{e f f} I \int_{0}^{L} \frac{\partial^{2} w}{\partial x^{2}} d x+\frac{1}{2} E_{e f f} A \int_{0}^{L} \frac{\partial^{2} u}{\partial x^{2}} d x \\
T_{e}=\frac{1}{2} \int_{0}^{L} \rho A\left(\dot{u}^{2}+\dot{w}^{2}\right) d x
\end{gathered}
$$

where $I$ is the second moment of inertia, $A$ denotes the cross-sectional area of the arch (curved) frame structure, and $\rho$ represents the density. Equations (11) and (12) can be written in matrix form as

$$
\begin{aligned}
& U_{e}=\frac{1}{2} \boldsymbol{q}^{\boldsymbol{T}} \boldsymbol{k}_{e} \boldsymbol{q} \\
& T_{e}=\frac{1}{2} \boldsymbol{q}^{\boldsymbol{T}} \boldsymbol{m}_{e} \boldsymbol{q}
\end{aligned}
$$

where $\mathbf{k}_{\mathrm{e}}$ and $\mathbf{m}_{\mathrm{e}}$ are the element elastic stiffness and mass matrices, respectively. The work done by the perpendicular distributed load (Goren Kiral et al., 2015) is

$$
V_{e}=\frac{1}{2} W \int_{0}^{L}\left(\frac{\partial v}{\partial x}\right)^{2} d x
$$

The matrix form of Equation (15) can be written as,

$$
V_{e}=\frac{1}{2} \boldsymbol{q}^{T} \boldsymbol{k}_{\boldsymbol{g} e} \boldsymbol{q}
$$

where $\mathbf{k}_{\mathbf{g e}}$ is the element geometric stiffness matrix. Since the laminated composite arch (curved) frame structure is composed of straight frame beam elements, element mass, elastic stiffness, and geometric stiffness matrices are needed to be transformed in therms of reference coordinates as is shown in Figure 5. Hence, those matrices are transformed considering the 3DOF element by using Equation (17). 
Daş O., Öztürk H., Gönenli C.: Dynamic Stabil. Analys. of the Laminated Compos. Curved Frame Struc.

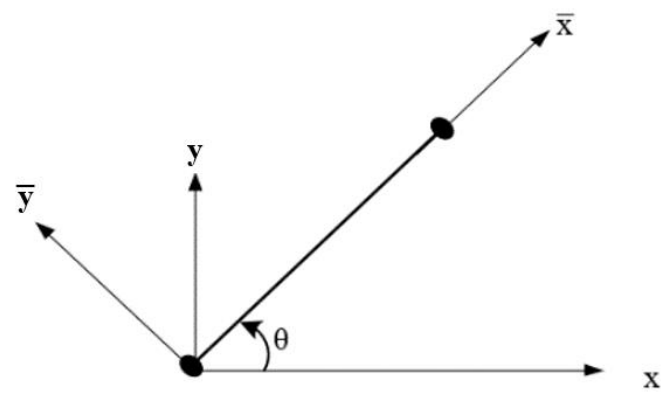

Figure 5:

Transformation of local coordinates

$$
\begin{aligned}
& \bar{k}_{e}=T^{T} \boldsymbol{k}_{e} T \\
& \overline{\boldsymbol{m}}_{e}=\boldsymbol{T}^{T} \boldsymbol{m}_{e} T \\
& \bar{k}_{g e}=T^{T} \boldsymbol{k}_{g e} T
\end{aligned}
$$

where $\mathbf{T}$ is the transformation matrix for $3 \mathrm{DOF}$, which is,

$$
\boldsymbol{T}=\left[\begin{array}{ccc}
\cos \theta & \sin \theta & 0 \\
-\sin \theta & \cos \theta & 0 \\
0 & 0 & 1
\end{array}\right]
$$

Bolotin (1964) indicated that considering $2 T=\pi / \lambda$ as period provides significant importance since the widths of the unstable regions are generally larger than those solved with period $T=$ $2 \pi / \lambda$. Hence, performing a periodic solution considering the period as $2 T$ on Equation (19) gives the eigenvalue problem of dynamic stability analysis as

$$
\left[\boldsymbol{K}-P_{c r}(\alpha \mp 0.5 \beta) \boldsymbol{K}_{g}-\frac{\lambda^{2}}{4} \boldsymbol{M}\right] \boldsymbol{q}=0
$$

\section{NUMERICAL RESULTS}

The Finite Element Method is employed to obtain the static and dynamic characteristics of the single-bay and two-bay laminated composite arch (curved) frame structures. The material and geometrical properties of such structures are given in Table 1 (Gay, 2014). All analyses are performed under fixed from all ends boundary conditions. The convergence analyses, given in Figure 6 and Table 2, are performed for 100, 150, 200, and 250 frame elements to check the validity of the mathematical model of the frame structure having $C 1$ stacking order and $R_{x x}=2 L_{b}$ radius of curvature. The number of elements considered for the ANSYS model is set as 30 . The best results are obtained for 250 frame elements.

The buckling analysis is conducted via MATLAB by considering the loading cases shown in Figures. 1 and 2. The dynamic characteristics of the laminated arch frame structures are performed considering five different stacking orders. For simlicity, those stacking orders are presented as 


$$
\begin{aligned}
& \mathrm{C} 1=\left[\left(0^{0}\right)_{4}\right], \mathrm{C} 2=\left[\left(90^{0} / 0^{0}\right)_{2}\right]_{\mathrm{s}}, \mathrm{C} 3=\left[\left(0^{0} / 90^{0}\right)_{2}\right]_{\mathrm{s}}, \\
& \mathrm{C} 4=\left[0^{0} / 45^{0} /-45^{0} / 0^{0}\right], \text { and } \mathrm{C} 5=\left[0^{0} / 60^{0} /-60^{0} / 0^{0}\right] .
\end{aligned}
$$

Table 1. Material properties and geometry of the structure of laminated composite arch (curved) frames

\begin{tabular}{|l|c|c|}
\hline Property & Symbol & Quantity \\
\hline Longitudinal Elasticity Modulus & $\mathrm{E}_{\mathrm{x}}$ & $45 \mathrm{GPa}$ \\
\hline Transverse Elasticity Modulus & $\mathrm{E}_{\mathrm{y}}$ & $12 \mathrm{GPa}$ \\
\hline Density & $\rho$ & $2080 \mathrm{~kg} / \mathrm{m}^{3}$ \\
\hline Poisson Ratio & \multicolumn{2}{|c|}{ Geometric Properties of the Structure } \\
\hline \multicolumn{2}{|c|}{$\mathrm{L}_{\mathrm{b}}$} & $1000 \mathrm{~mm}$ \\
\hline Beam Length & $\mathrm{R}_{\mathrm{xx}}$ & $2 \mathrm{~L}_{\mathrm{b}}$ \\
\hline \multirow{2}{*}{ Radius of Curvature (Standard) } & $\mathrm{h}$ & $\mathrm{L}_{\mathrm{b}} / 100$ \\
\hline \multirow{2}{*}{ Cross-section } & $\mathrm{b}$ & $\mathrm{L}_{\mathrm{b}} / 100$ \\
\cline { 2 - 4 }
\end{tabular}

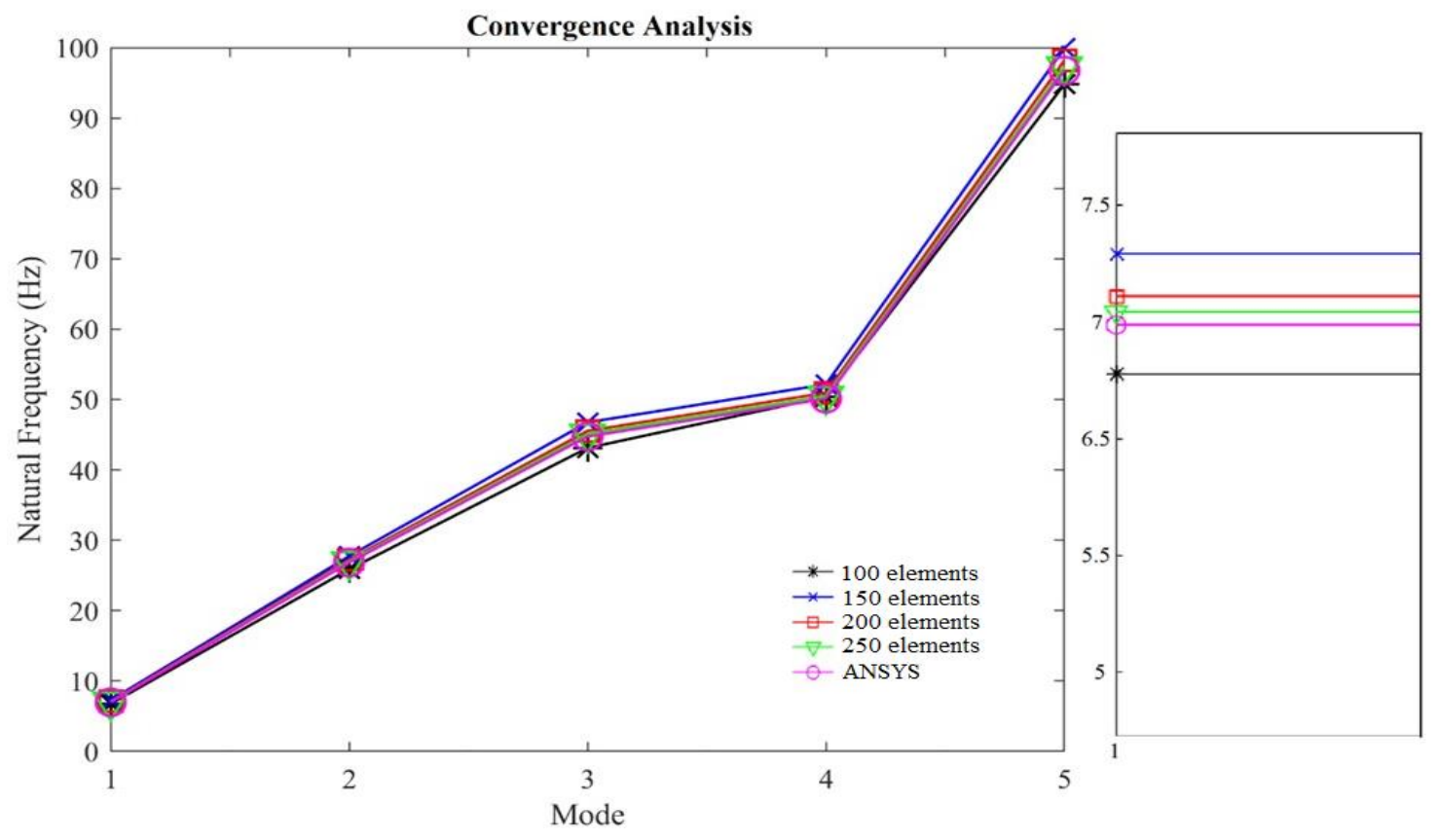

Figure 6:

Convergence analysis results of free vibration analysis of the C1 single-bay structure 
Daş O., Öztürk H., Gönenli C.: Dynamic Stabil. Analys. of the Laminated Compos. Curved Frame Struc.

Table 2. The convergence analysis results of the buckling analysis of the single-bay laminated composite arch frame structure having $R_{x x}=2 L_{b}$ radius of curvature and $C 1$ stacking order

\begin{tabular}{|l|c|c|c|}
\hline \multirow{2}{*}{ Number of Elements } & \multicolumn{3}{|c|}{ Critical Buckling Load $(\boldsymbol{N})$} \\
\cline { 2 - 4 } & $P S$ & $A N S Y S$ & Error $(\%)$ \\
\hline 100 & 593.850 & 546.550 & $8.65 \%$ \\
\hline 150 & 578.120 & 546.550 & $5.78 \%$ \\
\hline 200 & 572.590 & 546.550 & $4.76 \%$ \\
\hline 250 & 567.800 & 546.550 & $3.89 \%$ \\
\hline
\end{tabular}

\subsection{The Single-Bay Structure}

Table 3 gives the first five natural frequencies and the critical buckling load values of the single-bay arch (curved) frame structure having $\mathrm{C} 1$ stacking order and different radius of curvature values.

Table 3. Free vibration results of the $\mathrm{C} 1$ laminated composite single-bay arch frame structure having different radius of curvatures

\begin{tabular}{|l|c|c|c|c|}
\hline Natural Frequency (Hz) & $\mathbf{R}_{\mathbf{x x}}=\mathbf{1 . 5} \mathbf{L}_{\mathbf{b}}$ & $\mathbf{R}_{\mathbf{x x}}=\mathbf{2} \mathbf{L}_{\mathbf{b}}$ & $\mathbf{R}_{\mathbf{x x}}=\mathbf{2 . 5} \mathbf{L}_{\mathbf{b}}$ & $\mathbf{R}_{\mathbf{x x}}=\mathbf{3} \mathbf{L}_{\mathbf{b}}$ \\
\hline$\lambda_{1}$ & 6.952 & 6.986 & 7.002 & 7.012 \\
\hline$\lambda_{2}$ & 26.427 & 26.830 & 27.039 & 27.164 \\
\hline$\lambda_{3}$ & 44.445 & 44.737 & 44.890 & 44.984 \\
\hline$\lambda_{4}$ & 50.324 & 50.121 & 49.960 & 49.837 \\
\hline$\lambda_{5}$ & 95.571 & 96.738 & 97.305 & 97.630 \\
\hline Critical Buckling Load $(N)$ & 566.350 & 567.800 & 568.450 & 568.800 \\
\hline
\end{tabular}

According to the results given in Table 3, the first three and the fifth natural frequency values increase slightly as the radius of curvature of the laminate composite arch (curved) frame structure increases. In contrast, the fourth natural frequency decreases as the radius of the curvature of the structure increases. The critical buckling load changes in the same way as the radius of curvature changes. Figures. 7 and 8 show the instability region of the laminated composite arch (curved) frame structure with $\mathrm{C} 1$ stacking order and four different radii of curvatures for $\alpha=0$ and $\alpha=0.5$, respectively. It is inferred from Figures. 7 and 8 that increasing the radius of the curvature of the arch (curved) frame structure does not considerably affect the instability region. Thus, the difference between the first unstable regions of different curvatures is so small that it can be neglected. Besides, the unstable region widens as the dynamic load factor increases. These conditions are observed for structures having different stacking orders and the two-bay arch (curved) frame structures. 

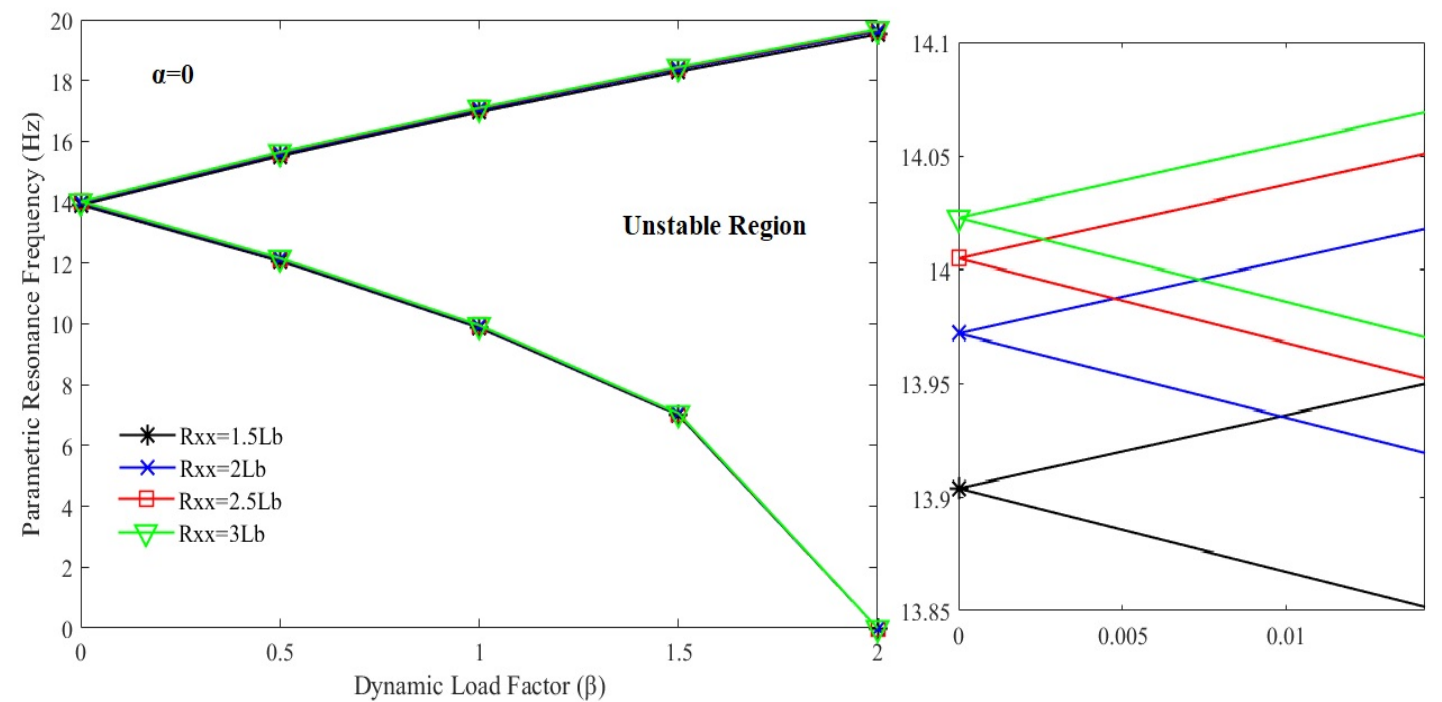

Figure 7:

The first unstable regions for $\alpha=0$ under different radius of curvatures
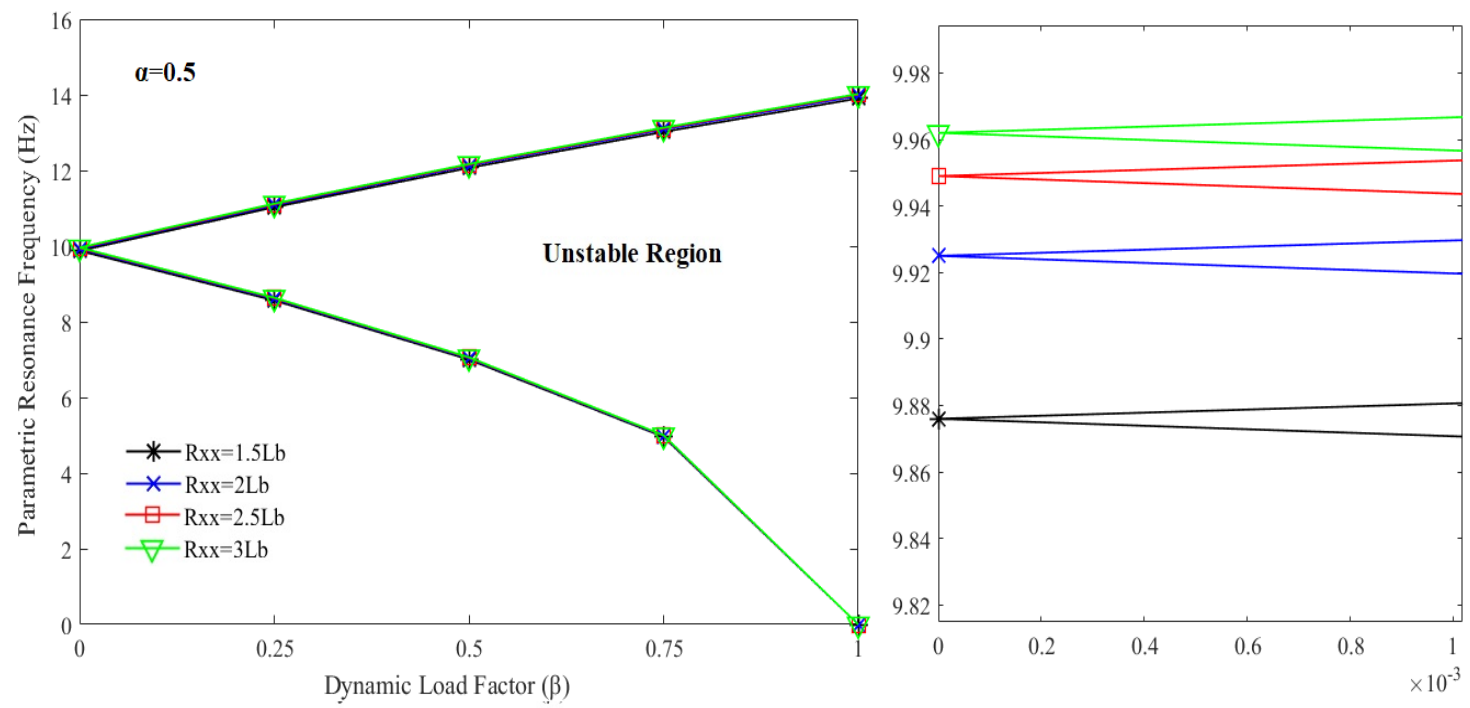

Figure 8:

The first unstable regions for $\alpha=0.5$ under different radius of curvatures

Table 4 gives the first five natural frequency results of the laminated composite arch frames having five different stacking orders. It is seen from Table 4 that the fiber angle of the second and the third layers, or in other words the mid-layers, do not affect the natural frequency values and the critical buckling load considerably. However, even the change is small, the natural frequencies and critical buckling load values decrease as the fiber angle of the mid-layers increases. On the other hand, the fiber angles of the first and the last layers have the most impact on the natural frequency and critical buckling load values. Such values decrease significantly as the fiber angles of the first and the last layers increases from $0^{\circ}$ to $90^{\circ}$. Such an incident occurs since those layers are subjected to bending forces more than the mid-layers. 
Daş O., Öztürk H., Gönenli C.: Dynamic Stabil. Analys. of the Laminated Compos. Curved Frame Struc.

Table 4. Free vibration and buckling analysis results of the laminated composite singlebay arch frame structure having different stacking orders for $\mathbf{R}_{\mathrm{xx}}=\mathbf{2} \mathbf{L}_{\mathrm{b}}$

\begin{tabular}{|l|c|c|c|c|c|}
\hline Natural Frequency (Hz) & C1 & C2 & C3 & C4 & C5 \\
\hline$\lambda_{1}$ & 6.986 & 4.191 & 6.673 & 6.741 & 6.687 \\
\hline$\lambda_{2}$ & 26.830 & 16.097 & 25.628 & 25.889 & 25.682 \\
\hline$\lambda_{3}$ & 44.737 & 26.840 & 42.732 & 43.168 & 42.823 \\
\hline$\lambda_{4}$ & 50.121 & 30.070 & 47.875 & 48.363 & 47.976 \\
\hline$\lambda_{5}$ & 96.738 & 58.037 & 92.402 & 93.344 & 92.597 \\
\hline Critical Buckling Load $(N)$ & 567.800 & 204.370 & 518.040 & 528.660 & 520.230 \\
\hline
\end{tabular}

Figures 9 and 10 show the dynamic instability region of the laminated composite arch (curved) frame structures having different stacking orders. It is concluded that the unstable region is almost the same for arch (curved) frame structures having $\mathrm{C} 1, \mathrm{C} 3, \mathrm{C} 4$, and $\mathrm{C} 5$. The distance of the unstable regions to the origin can be ordered from the closest to farthest as $\mathrm{C} 2, \mathrm{C} 3, \mathrm{C} 5, \mathrm{C} 4$, and $\mathrm{C} 1$, respectively. Although the unstable regions of $\mathrm{C} 1, \mathrm{C} 3, \mathrm{C} 4$, and $\mathrm{C} 5$ are similar, the unstable region of $\mathrm{C} 2$ is quite different. Such difference occurs since the fiber angles first and last layers of $\mathrm{C} 2$ are $90^{\circ}$ degrees which lower the stiffness of the structure considerably. When the static load factor decreases, the unstable region becomes wider and moves further from the origin regardless of stacking orders.
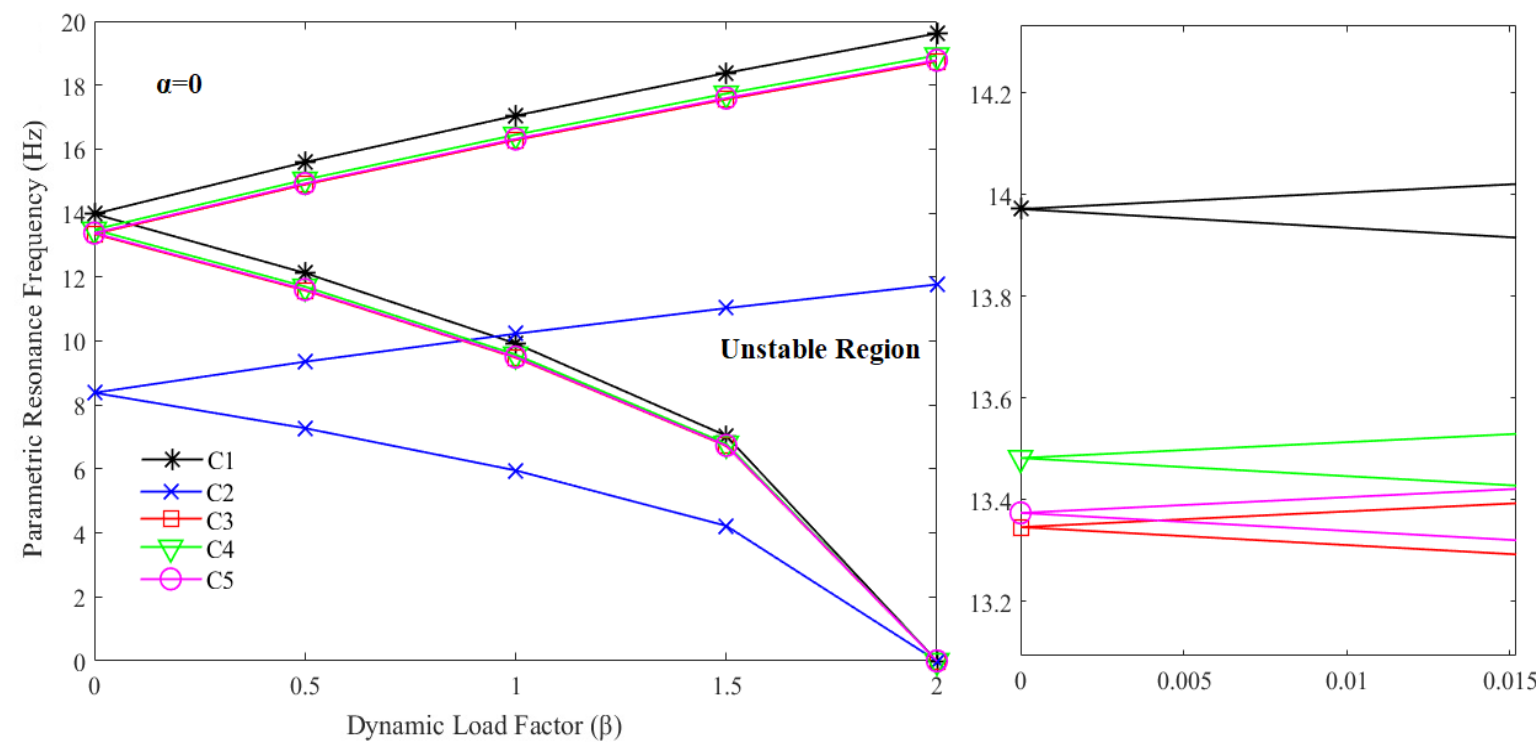

Figure 9:

The first unstable regions for $\alpha=0$ under different fiber orientations 

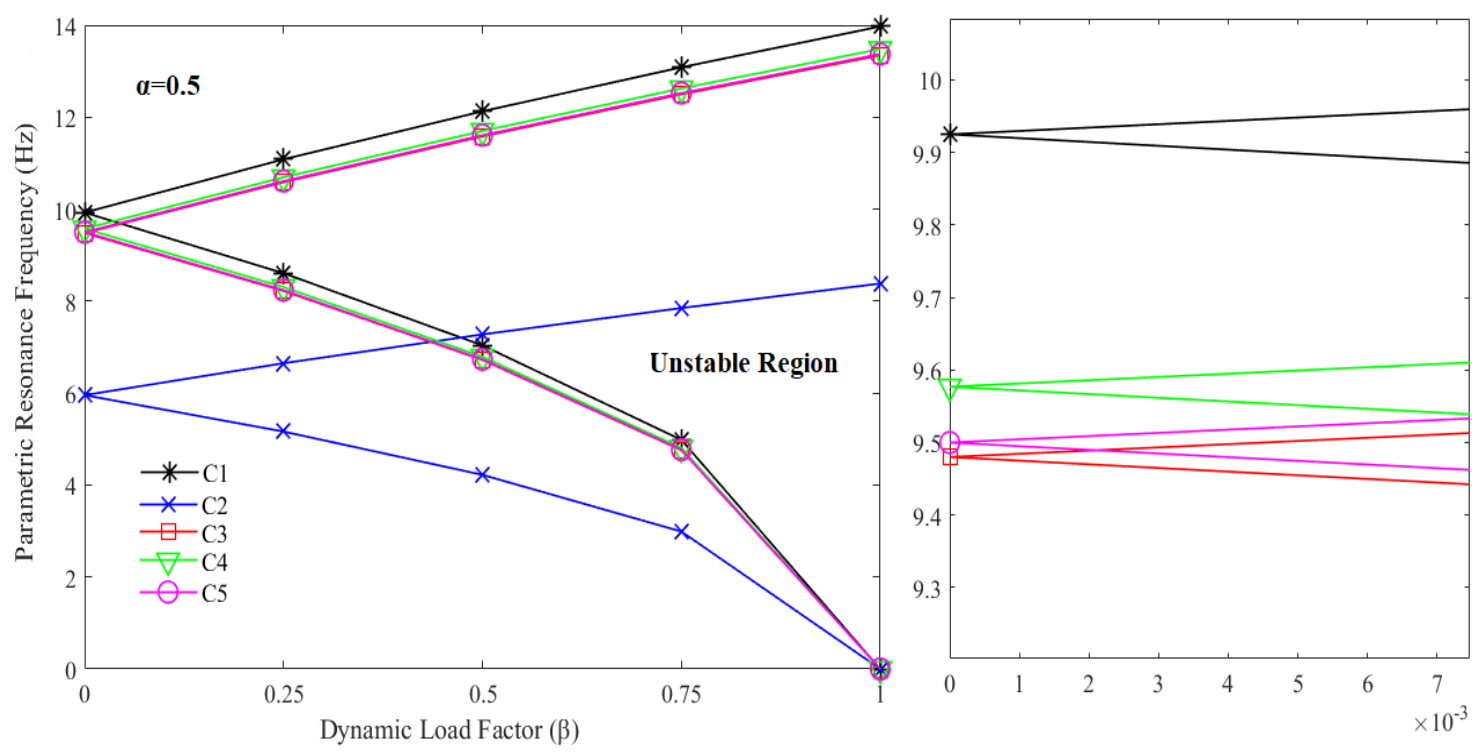

Figure 10:

The first unstable regions for $\alpha=0.5$ under different fiber orientations

\subsection{The Two-Bay Structure}

Table 5 gives the first five natural frequencies and the critical buckling load values of the laminated composite two-bay arch frame structure having $\mathrm{C} 1$ stacking order considering four different radii of curvatures.

Table 5. Free vibration and buckling analyses results of the $\mathrm{C} 1$ laminated composite twobay curved frame structure having different radius of curvatures

\begin{tabular}{|l|c|c|c|c|}
\hline Natural Frequency $(\mathbf{H z})$ & $\mathbf{R}_{\mathbf{x x}}=\mathbf{1 . 5 \mathbf { L } _ { \mathbf { b } }}$ & $\mathbf{R}_{\mathbf{x x}}=\mathbf{2} \mathbf{L}_{\mathbf{b}}$ & $\mathbf{R}_{\mathbf{x x}}=\mathbf{2 . 5 \mathbf { L } _ { \mathbf { b } }}$ & $\mathbf{R}_{\mathbf{x x}}=\mathbf{3} \mathbf{L}_{\mathbf{b}}$ \\
\hline$\lambda_{1}$ & 6.169 & 6.197 & 6.210 & 6.521 \\
\hline$\lambda_{2}$ & 25.823 & 26.171 & 26.337 & 26.505 \\
\hline$\lambda_{3}$ & 33.243 & 33.773 & 34.001 & 32.901 \\
\hline$\lambda_{4}$ & 41.510 & 41.642 & 41.736 & 45.499 \\
\hline$\lambda_{5}$ & 50.098 & 50.073 & 49.935 & 49.925 \\
\hline Critical Buckling Load $(N)$ & 799.980 & 801.560 & 802.210 & 875.860 \\
\hline
\end{tabular}

According to the natural frequency results given in Table 5, the first four natural frequency values increase, while the fifth natural frequency value decreases as the curvature of the frame structure increases. The critical buckling load increases as the radius of curvature of the two-bay laminated composite curved frame structure increases. Similar behaviors are seen for all stacking orders. Table 6 gives the first five natural frequency and critical buckling load values of the twobay laminated composite arch frame structure having different stacking orders. It is seen from Table 6 that the stacking order has the same impact on the natural frequency and critical buckling load values as in the single-bay structure. Apart from the fifth natural frequency value, the natural frequency values decrease slightly when compared with the single-bay structure. The fifth natural frequency, on the other hand, falls significantly due to the shifts and changes in mode shapes of the structure shown in Appendices B and C. 
Daş O., Öztürk H., Gönenli C.: Dynamic Stabil. Analys. of the Laminated Compos. Curved Frame Struc.

Table 5. Free vibration and buckling analysis results of the laminated composite two-bay curved frame structure having different stacking orders for $\mathbf{R}_{\mathrm{xx}}=\mathbf{2} \mathbf{L}_{\mathrm{b}}$

\begin{tabular}{|l|c|c|c|c|c|}
\hline Natural Frequency $(\boldsymbol{H z})$ & $\boldsymbol{C 1}$ & $\boldsymbol{C 2}$ & $\boldsymbol{C 3}$ & $\boldsymbol{C 4}$ & $\boldsymbol{C 5}$ \\
\hline$\lambda_{1}$ & 6.197 & 3.718 & 5.919 & 5.979 & 5.932 \\
\hline$\lambda_{2}$ & 26.171 & 15.701 & 24.998 & 25.253 & 25.051 \\
\hline$\lambda_{3}$ & 33.773 & 20.262 & 32.259 & 32.588 & 32.328 \\
\hline$\lambda_{4}$ & 41.642 & 24.983 & 39.776 & 40.182 & 39.860 \\
\hline$\lambda_{5}$ & 50.073 & 30.041 & 47.829 & 48.317 & 47.930 \\
\hline Critical Buckling Load $(N)$ & 801.560 & 288.500 & 731.320 & 746.310 & 734.410 \\
\hline
\end{tabular}

Figures 11 and 12 show the first unstable regions of the laminated composite arch (curved) two-bay frame structures having different stacking orders. It is seen from Figures 11 and 12 that the first unstable regions of two-bay arch (curved) frame structures have the same behavior as those of the single-bay structure. Likewise, the unstable region reaches its closest distance to the origin as the structure has $\mathrm{C} 2$ stacking order. The unstable regions move toward the origin and become narrow as the static load factor increases. Comparing with the first unstable regions obtained for the single-bay structure, the unstable regions of the two-bay structure move slightly towards origin because of being a two-bay structure.
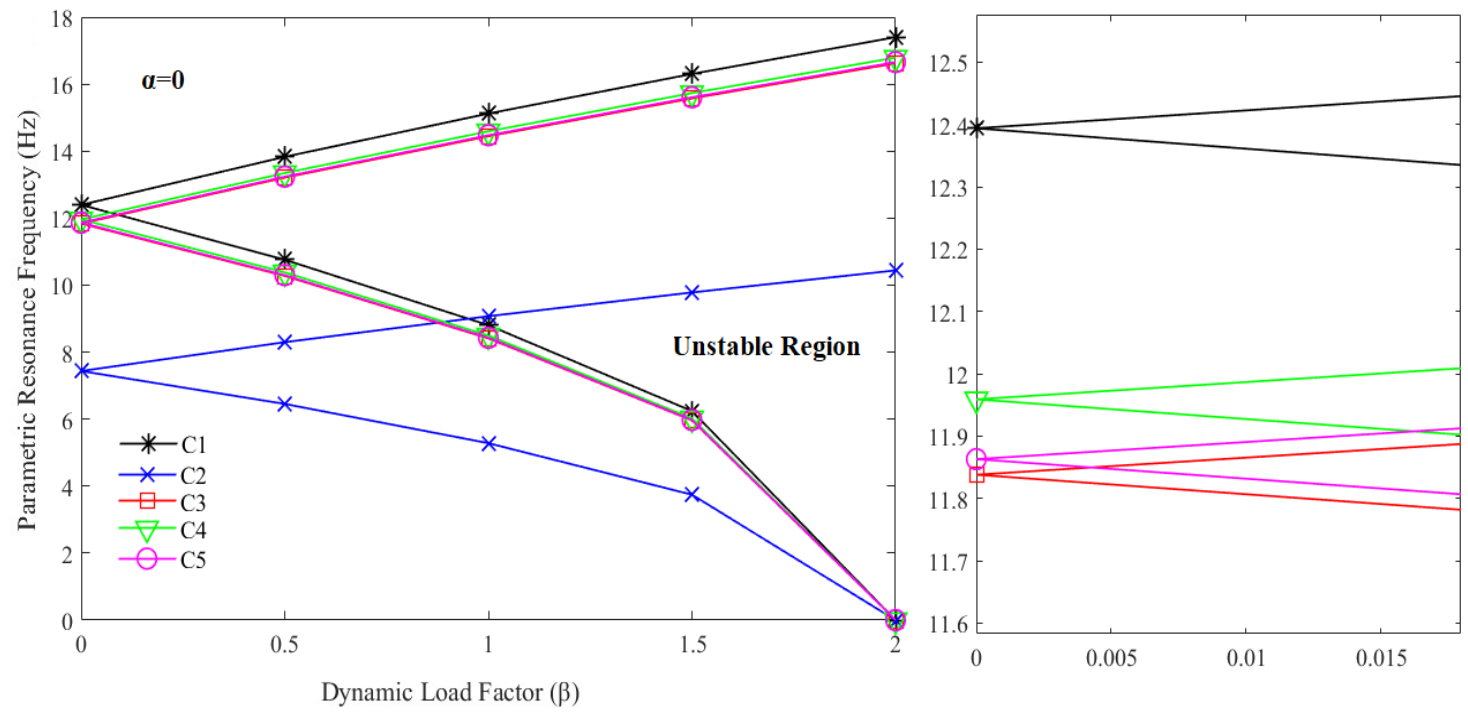

The first unstable regions of the two-bay structure for $\alpha=0$ under different fiber orientations 

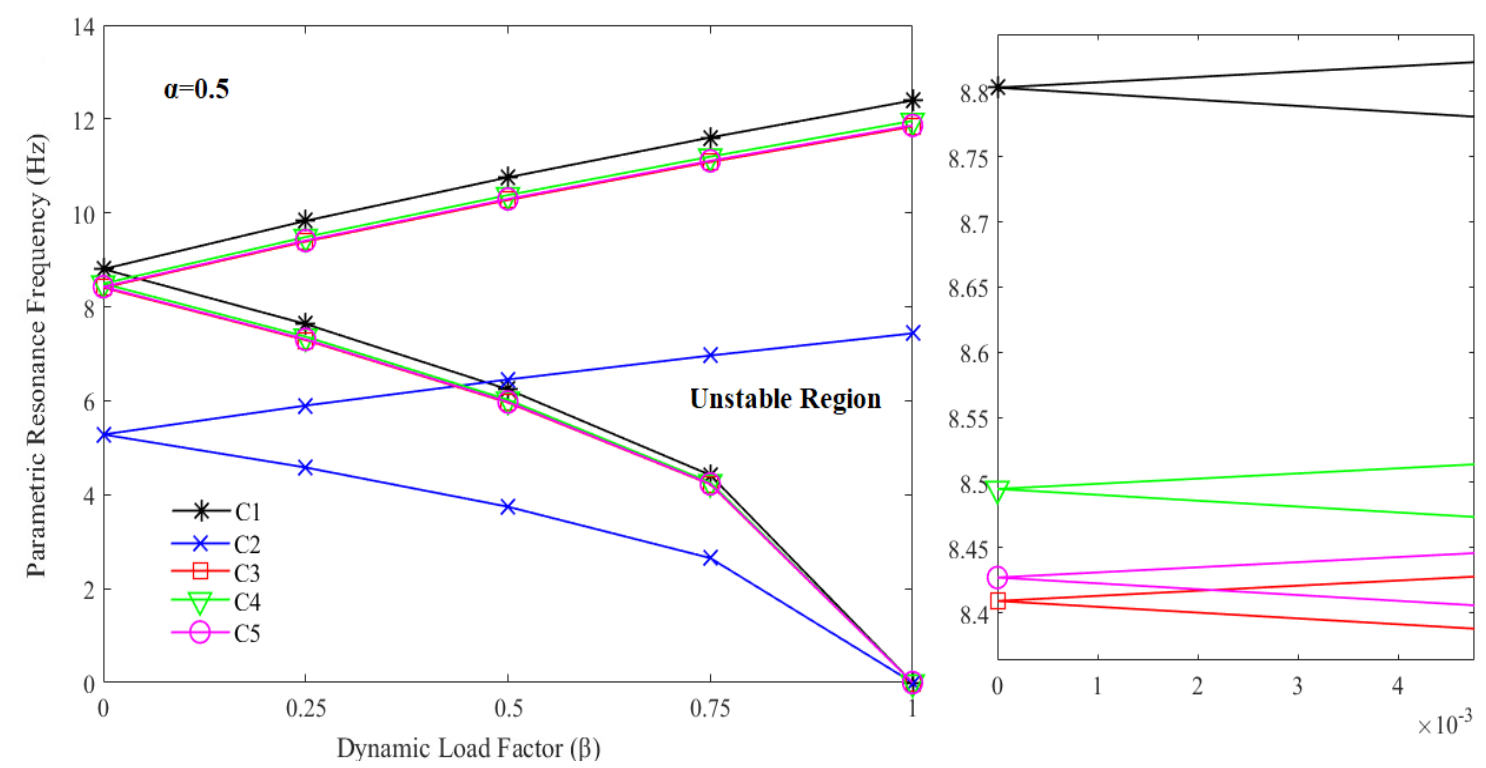

Figure 11:

The first unstable regions of the two-bay structure for $\alpha=0.5$ under different fiber orientations

The mode shapes of single-bay and two-bay laminated composite arch (curved) frame structure, shown in Appendices B and C, are similar to each other except for the fifth and fourth modes, which are shifted to each other when the structure has two-bay instead of single-bay. Besides, the stacking order does not affect the mode shapes of both single-bay and two-bay arch (curved) frame structures. It is inferred from the results given in this section that the fiber angles of the first and the last laminate have the most impact on natural frequency values, whereas the effect of the fiber angles of the middle laminates is quite small. Hence considering $R_{x x}=2 L_{b}$, the ranking of the fundamental natural frequency values and critical buckling load of the corresponding stacking order from the lowest to the highest value is $\mathrm{C} 2, \mathrm{C} 3, \mathrm{C} 5, \mathrm{C} 4$, and $\mathrm{C} 1$, respectively. As a result, the change in the radius of curvature of the laminated composite arch frame structures does not affect the first five natural frequencies and critical buckling load of the structure considerably. On the other hand, the stacking order has a significant impact on the natural frequencies and critical buckling load value of the structure. However, both changing the radius of curvature or the stacking order does not shift the mode shapes, as seen from Appendices $\mathrm{B}$ and $\mathrm{C}$.

\section{CONCLUSIONS}

This study has investigated the dynamic analysis of laminated composite arch (curved) frame structures using the finite element method. Classical Plate Theory is employed to satisfy the stress and strain conditions of the arch (curved) frame structure. According to the results of this work, the following conclusions are drawn.

- The changes in the radius of curvature affect slightly the natural frequency values, critical buckling values, and the instability region of the laminated composite arch (curved) frame structures.

- The first three and fifth natural frequency values of single-bay laminated composite arch (curved) frame structures increase. In contrast, the fourth natural frequency decreases as the radius of curvature of the frame structure increases. For the two-bay arch (curved) frame structure, the 
Daş O., Öztürk H., Gönenli C.: Dynamic Stabil. Analys. of the Laminated Compos. Curved Frame Struc.

first four natural frequency values increase while the fifth natural frequency decreases as the radius of curvature of the structure increases.

- The single-bay and two-bay structures differ from each other in terms of their response to the variations in the radius of curvature due to the shift between mode shapes (see Appendices B and C).

- The mode shapes do not change with respect to the stacking order or the radius of curvature of the single-bay and two-bay laminated composite arch (curved) frame structures.

- The critical buckling load values increase as the radius of curvature of the laminated composite arch (curved) frame structure increases, no matter which stacking order the arch (curved) frame structures have.

- The unstable region moves slightly towards the origin as the radius of curvature of the laminated composite arch (curved) frame structure decreases.

- It is inferred from the numerical results that the fiber angle has a significant effect on the natural frequency values, critical buckling load values, and first unstable regions of both single and two-bay structures. The highest impact on such properties is caused by the fiber angle of the material's first and the last layer. Hence, the effect of $\mathrm{C} 1, \mathrm{C} 3, \mathrm{C} 4$, and $\mathrm{C} 5$ on the dynamical and buckling characteristics of laminated composite arch (curved) frame structures is negligible, whereas the effect of $\mathrm{C} 2$ is considerable.

- It is concluded from the numerical results that applying $\mathrm{C} 2$ as the stacking order for laminated composite arch (curved) frame structure decreases the natural frequency values and critical buckling loads, narrows and moves the unstable region to the origin when compared with other stacking orders $\mathrm{C} 1, \mathrm{C} 3, \mathrm{C} 4$, and $\mathrm{C} 5$.

\section{CONFLICT OF INTEREST}

All authors approve that there is no conflict of interest with any institutions/organizations or individuals.

\section{AUTHOR CONTRIBUTIONS}

Oğuzhan Daş: Determination of conceptual and/or design processes of the study, management of conceptual and/or design processes of the study, data collecting, data analysis and interpretation, writing the draft of the manuscript, reviewing the intellectual content, final approval and full responsibility of the study. Hasan Öztürk: Determination of conceptual and/or design processes of the study, management of conceptual and/or design processes of the study, data analysis and interpretation, reviewing the intellectual content, final approval and full responsibility of the study. Can Gönenli: Data analysis and interpretation, reviewing the intellectual content, final approval and full responsibility of the study.

\section{REFERENCES}

1. Alambeigi, K., Mohammadimehr, M., Bamdad, M. \& Rabczuk, T. (2020). Free and forced vibration analysis of a sandwich beam considering porous core and SMA hybrid composite face layers on Vlasov's foundation. Acta Mechanica, 231,3199-3218. https://doi.org/10.1007/s00707-020-02697-5

2. Bolotin, V. V. (1964). The dynamic stability of elastic systems. Holden-Day, San Fransisco.

3. Eken, S. (2019). Free Vibration Analysis of Composite Aircraft Wings Modeled as ThinWalled Beams with NACA Airfoil Sections. Thin-Walled Structures, 139,362-371. https://doi.org/10.1016/j.tws.2019.01.042

4. Gay, D. (2014). Composite Materials: Design and Applications. CRC Press, Florida 
5. Glabisz, W., Jarczewska, K. \& Hołubowski, R. (2020). Stability of nanobeams under nonconservative surface loading. Acta Mechanica, 231,3703-3714. https://doi.org/10.1007/s00707-020-02732-5

6. Goren Kiral, B., Kiral, Z. \& Ozturk, H. (2015). Stability Analysis of Delaminated Composite Beams. Composites Part B: Engineering, 79, 406-418. https://doi.org/10.1016/j.compositesb.2015.05.008

7. Goyal, V.K. \& Kapania, R.K. (2007). A Shear-Deformable Beam Element for the Analysis of Laminated Composites. Finite Elements in Analysis and Design, 43(6-7), 463-477. https://doi.org/10.1016/j.finel.2006.11.011

8. He, G. \& Yang, X. (2014). Finite Element Analysis for Buckling of Two-Layer Composite Beams Using Reddy's Higher Order Beam Theory. Finite Elements in Analysis and Design, 83, 49-57. https://doi.org/10.1016/j.finel.2014.01.004

9. Hodges, D. H., Atilgan, A. R., Fulton, M. V. \& Rehfield, L. W. (1991). Free-Vibration Analysis of Composite Beams. Journal of American Helicopter Society, 36(3):36-47. https://doi.org/10.4050/JAHS.36.36

10. Huang, S. \& Qiao, P. (2020). Buckling of Thin-Walled I-Section Laminated Composite Curved Beams. Thin-Walled Structures, 154, https://doi.org/10.1016/j.tws.2020.106843

11. Kahya, V. (2016). Buckling Analysis of Laminated Composite and Sandwich Beams by the Finite Element Method. Composites Part B: Engineering, 91, 126-134. https://doi.org/10.1016/j.compositesb.2016.01.031

12. Ke, L.L., Yang, J. \& Kitipornchai, S. (2013). Dynamic Stability of Functionally Graded Carbon Nanotube-Reinforced Composite Beams. Mechanics of Advanced Materials and Structures, 20(1), 28-37. https://doi.org/10.1080/15376494.2011.581412

13. Lee, J. \& Kim, S.E. (2002). Lateral Buckling Analysis of Thin-Walled Laminated ChannelSection Beams. Composite Structures, 56(4), 391-399. https://doi.org/10.1016/S02638223(02)00022-3

14. Machado, S.P. \& Cortínez, V.H. (2009). Dynamic Stability of Thin-Walled Composite Beams under Periodic Transverse Excitation. Journal of Sound and Vibration, 321(1-2), 220-241. https://doi.org/10.1016/j.jsv.2008.09.026

15. Marur, S.R. \& Kant, T. (1996). Free Vibration Analysis of Fiber Reinforced Composite Beams Using Higher Order Theories and Finite Element Modelling. Journal of Sound and Vibration, 194(3),337-351. https://doi.org/10.1006/jsvi.1996.0362

16. Ozturk, H. (2015). Vibration Analysis of a Pre-Stressed Laminated Composite Curved Beam. Steel and Composite Structures, 19(3), 635-659. https://doi.org/10.12989/scs.2015.19.3.635

17. Öztürk, H., Yeşilyurt, I. \& Sabuncu, M. (2006). In-Plane Stability Analysis of Non-Uniform Cross-Sectioned Curved Beams, Journal of Sound and Vibration, 296(1-2), 277-291. https://doi.org/10.1016/j.jsv.2006.03.002

18. Petyt, M. (2010). Introduction to Finite Element Vibration Analysis. Cambridge University Press, New York.

19. Qin, B., Zhao, X., Liu, H., Yu, Y., \& Wang, Q. (2020). Free Vibration Analysis of Curved Laminated Composite Beams with Different Shapes, Lamination Schemes, and Boundary Conditions. Materials, 13(4),1010, https://doi.org/10.3390/ma13041010 
Daş O., Öztürk H., Gönenli C.: Dynamic Stabil. Analys. of the Laminated Compos. Curved Frame Struc.

20. Saravia, C.M., Machado, S.P. \& Cortínez, V.H. (2011). Free Vibration and Dynamic Stability of Rotating Thin-Walled Composite Beams. European Journal of Mechanics - A/Solids, 30(3), 432-441. https://doi.org/10.1016/j.euromechsol.2010.12.015

21. Smoljanović, H., Balić, I., Munjiza, A., Akmadžić, V. \& Trogrlić, B. (2020). Analysis of dynamic stability of beam structures. Acta Mechanica, 231, 4701-4715. https://doi.org/10.1007/s00707-020-02793-6

22. Tsai, X.Y. \& Chen, L.W. (2002). Dynamic Stability of a Shape Memory Alloy Wire Reinforced Composite Beam. Composite Structures, 56(3), 235-241. https://doi.org/10.1016/S0263-8223(02)00008-9

23. Vo, T. P., Thai, H.T. \&Aydogdu, M. (2017). Free Vibration of Axially Loaded Composite Beams Using a Four-Unknown Shear and Normal Deformation Theory. Composite Structures, 178, 406-414.

24. Vo-Duy, T., Ho-Huu, V. \& Nguyen-Thoi, T. (2019). Free Vibration Analysis of Laminated FG-CNT Reinforced Composite Beams Using Finite Element Method. Frontiers of Structural and Civil Engineering, 13(2),324-336. https://doi.org/10.1016/j.compstruct.2017.07.022

25. Wang, X., Zhu, X. \& Hu, P. (2015). Isogeometric Finite Element Method for Buckling Analysis of Generally Laminated Composite Beams with Different Boundary Conditions. International Journal of Mechanical Sciences, 104, 190-199. https://doi.org/10.1016/j.ijmecsci.2015.10.008

26. Yeh, M.K. \& Kuo, Y.T. (2004). Dynamic Instability of Composite Beams under Parametric Excitation. Composite Sciences and Technology, 64(12), 1885-1893. https://doi.org/10.1016/j.compscitech.2004.02.001

27. Zabihollah, A. \& Ganesan, R. (2010). Buckling Analysis of Tapered Composite Beams Using a Higher Order Finite Element Formulation. Journal of Reinforced Plastics and Composites, 29(17), 2663-2683. https://doi.org/10.1177\%2F0731684409352124

\section{Appendix A}

$$
\begin{gathered}
Q_{11}=q_{11} c^{4}+2\left(q_{12}+2 q_{16}\right) s^{2} c^{2}+q_{22} s^{4} \\
Q_{12}=\left(q_{11}+q_{22}-4 q_{66}\right) s^{2} c^{2}+q_{12}\left(s^{4}+c^{4}\right) \\
Q_{22}=q_{22} c^{4}+2\left(q_{12}+2 q_{16}\right) s^{2} c^{2}+q_{11} s^{4} \\
Q_{16}=\left(q_{11}-q_{22}-2 q_{66}\right) s c^{3}+\left(q_{12}-q_{22}+2 q_{66} s^{3} c\right) \\
Q_{26}=\left(q_{11}-q_{22}-2 q_{66}\right) s^{3} c+\left(q_{12}-q_{22}+2 q_{66} s c^{3}\right) \\
Q_{66}=\left(q_{11}+q_{22}-2 q_{12}-2 q_{66}\right) s^{2} c^{2}+q_{66}\left(s^{4}+c^{4}\right)
\end{gathered}
$$

$\mathrm{c}=\cos \theta$ and $\mathrm{s}=\sin \theta$ where $\theta$ is the fiber angle

$$
\begin{array}{ccc}
q_{11}=\frac{E_{x}}{1-\vartheta_{x y} \vartheta_{y x}} & q_{12}=\frac{\vartheta_{x y} E_{y}}{1-\vartheta_{x y} \vartheta_{y x}} & q_{12}=\frac{E_{y}}{1-\vartheta_{x y} \vartheta_{y x}} \\
q_{66}=G_{x y} & E_{x} \vartheta_{x y}=E_{y} \vartheta_{y x}
\end{array}
$$

where $\mathrm{E}_{\mathrm{x}}$ and $\mathrm{E}_{\mathrm{y}}$ are the modulus of elasticity in $\mathrm{x}$ - and $\mathrm{y}$ - direction, respectively, and,

$\vartheta_{x y}:$ Strain value in the $\mathrm{x}$-direction because of the unit strain in y-direction

$\vartheta_{y x}$ : Strain value in the y-direction because of the unit strain in $\mathrm{x}$-direction 
Uludağ University Journal of The Faculty of Engineering, Vol. 26, No. 2, 2021

\section{Appendix B}
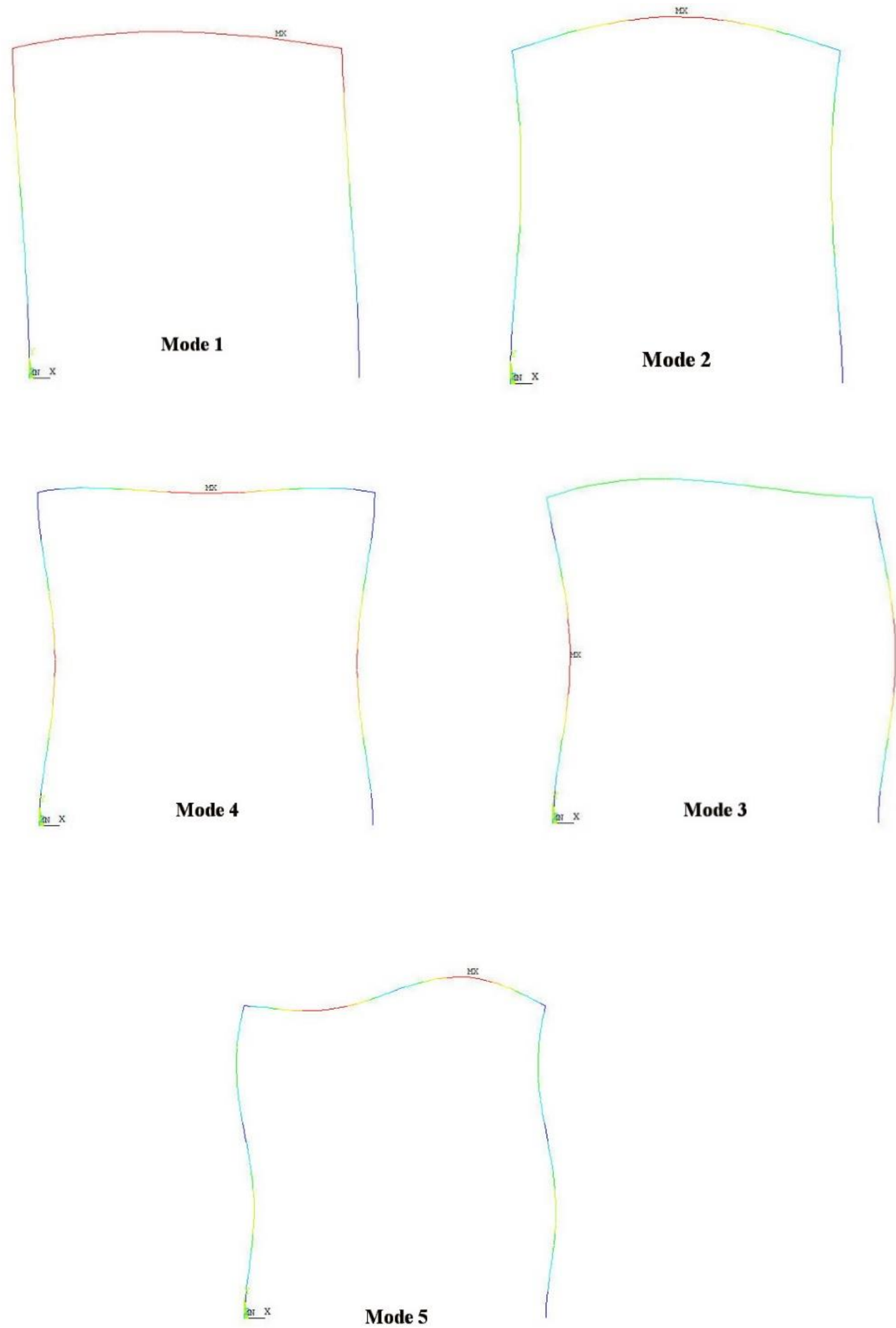
Daş O., Öztürk H., Gönenli C.: Dynamic Stabil. Analys. of the Laminated Compos. Curved Frame Struc.

\section{Appendix C}

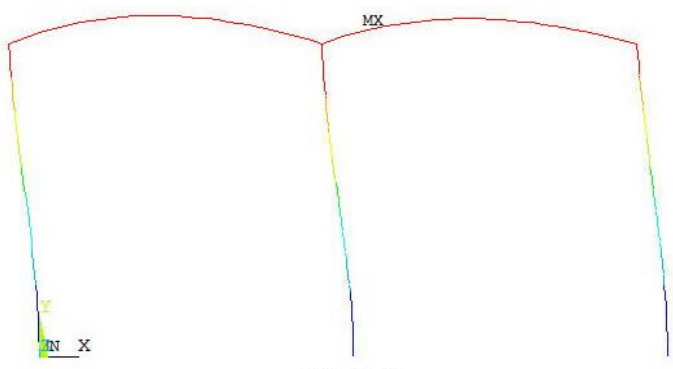

Mode 1

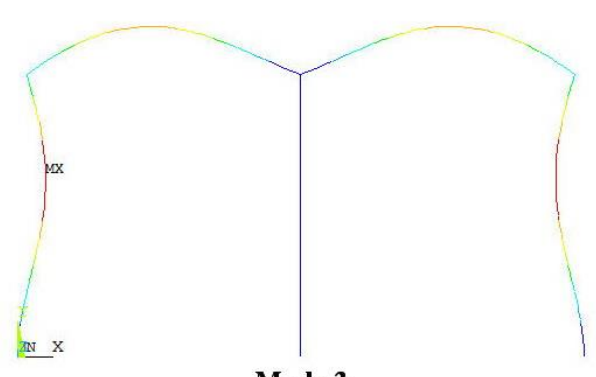

Mode 3

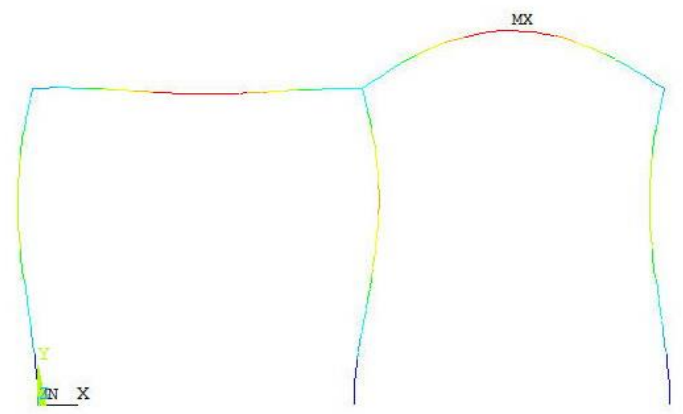

Mode 2

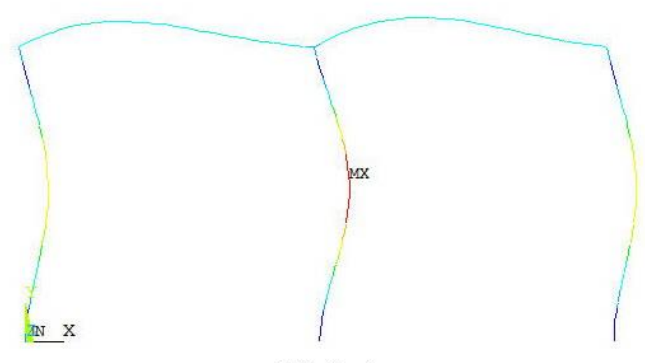

Mode 4

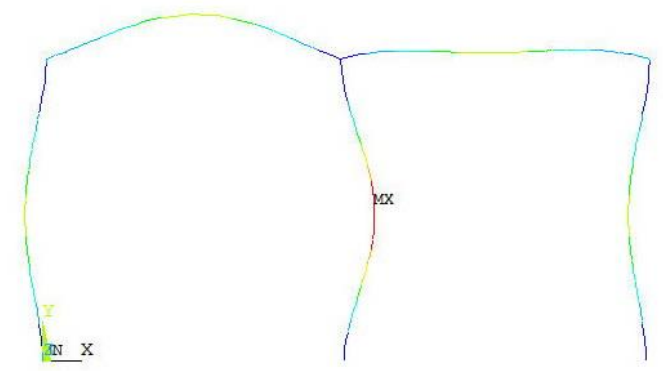

Mode 5 